\title{
Advanced Hodgkin's lymphoma: Results in 216 patients treated with ABVD in Brazil
}

\author{
Linfoma de Hodgkin em estádio avançado: Resultados do tratamento em 216 pacientes tratados \\ com ABVD no Brasil
}

\author{
Luciana Britto ${ }^{l}$ \\ Irene Biasoli ${ }^{1}$ \\ Denize Azambuja \\ Adriana Scheliga ${ }^{2}$ \\ Andrea Soares ${ }^{3}$ \\ Munya Gandour ${ }^{1}$ \\ Tatiana Hofmeister \\ Thiago Vieites ${ }^{1}$ \\ Cristiane Milito $^{I}$ \\ Wolmar Pulcheri ${ }^{1}$ \\ José Carlos Morais ${ }^{1}$ \\ Nelson Spector ${ }^{l}$
}

\begin{abstract}
The outcome of Hodgkin's lymphoma (HL) has markedly improved over the last few decades, placing HL among the human cancers with highest cure rates. However, data about treatment outcomes in developing countries are scarce. From 1996 to 2005, 370 consecutive patients with HL treated in three public institutions in Rio de Janeiro were identified. A total of 216 patients who presented with advanced stage (IIB-IV) HL were selected for the present analysis. Patients with advanced disease were treated with $A B V D$, complemented or not by radiation therapy. The median follow-up time of survivors was 6.3 years (1-11.8). Fifteen patients died during first-line treatment. The complete remission rate was $80 \%$. The 5-year progression-free survival (PFS) and the 5-year overall survival (OS) probabilities were $69 \%$ and $83 \%$, respectively. The 5-year PFS in low-risk and high-risk patients were $81 \%$ and $62 \%(p=0.003)$, respectively. The 5-year OS in low-risk and high-risk International Prognostic Score patients were $89 \%$ and $78 \%(p=0.02)$, respectively. The present study provides a representative estimate of current treatment results for advanced HL in public institutions in an urban area in Brazil. It is clear that full treatment can be given to most patients, although those with very low socio-economic status might require special attention and support. Since Brazil is a large country, with substantial interregional heterogeneity, a nationwide registry of $H L$ patients is currently being implemented. Rev. Bras. Hematol. Hemoter. 2010;32(4):303-307.
\end{abstract}

Key words: Hodgkin disease; chemotherapy; lymphoma.

\section{Introduction}

The outcome of Hodgkin's lymphoma (HL) has markedly improved over the last few decades. Randomized clinical trials conducted by cooperative groups in North America and Europe have identified treatment schedules that provide higher efficacy and lower toxicity, placing HL among the human cancers with highest cure rates.

However, data about treatment outcomes in developing countries are scarce. The aim of this study was to retrospectively analyze the treatment results of advanced stage HL patients treated 'off-protocol' in a community setting, at three public hospitals in Rio de Janeiro.

\section{Patients and methods}

Patients' characteristics

From 1996 to 2005, 370 consecutive patients with Hodgkin's Lymphoma (HL), treated on initial diagnosis in

${ }^{I}$ Departments of Medicine and Pathology, University Hospital and School of Medicine, Federal University of Rio de Janeiro, Brazil

${ }^{2}$ Pathology and Oncology Services, Instituto Nacional de Câncer, Brazil.

${ }^{3}$ University Hospital and School of Medicine, State University of Rio de Janeiro, Brazil.

Correspondence: Irene Biasoli

Address: Rua General Dionisio 19/302

22271-050 - Rio de Janeiro-RJ - Brazil

Phone: (55 21) 8126-9006; fax: (55 21) 2542-8145

E-mail: irene.biasoli@gmail.com

Doi: 10.1590/S1516-84842010005000089 
three public institutions in Rio de Janeiro, were identified and included in the database. A total of 216 patients who presented with advanced stage (IIB-IV) HL were selected for the present analysis. Diagnoses were confirmed on review by three authors using criteria defined in the WHO classification. ${ }^{1}$ Expression of CD30 was required for inclusion. Patients with positive HIV serology were excluded. All patients were staged according to the Ann Arbor system. The following baseline clinical characteristics were recorded: gender, age, stage, presence of bulky disease or B symptoms, performance status (ECOG) and blood counts. The International Prognostic Score (IPS) was determined for all patients. Patients were categorized as low risk IPS if they presented with up to two risk factors and as high risk IPS if three or more risk factors were present.

\section{Treatment and response evaluation}

All patients were treated with curative intent. Patients with advanced disease were treated with 6-8 cycles of ABVD (doxorubicin, bleomycin, vinblastine and dacarbazine), complemented or not by radiation therapy according to the attending physician's discretion. Patients who failed primary therapy received either salvage chemotherapy or high-dose chemotherapy with autologous stem cell transplantation.

Response was assessed one month after the end of treatment. Complete remission was defined as the disappearance of all clinical and radiologic evidence of disease.

\section{Statistical analysis}

Comparison of categorical variables was performed with the Fisher's exact test (two-sided), while the MannWhitney test was used for numeric data. Overall survival was defined as the time interval between the date of diagnosis and the date of death or last follow-up. Progression-free survival was defined as the time interval between the date of initial diagnosis and the date of disease progression or death from any cause, whichever came first. Survival curves were estimated using the product-limit method of Kaplan-Meier and were compared using the log-rank test. The SPSS version 15.0 software (Chicago, IL, USA) was used for data analysis.

\section{Results}

A total of 216 advanced stage patients were included in the study. Their median age was 30 years (range, 15-82 years), with 24 being over 60 years of age. The patients' clinical characteristics at diagnosis are shown in Table 1.

Seventy-seven patients (36\%) were treated with 6 to 8 chemotherapy cycles plus radiotherapy $(\mathrm{CT}+\mathrm{RT})$ and 113
Table 1. Clinical characteristics of advanced stage patients at diagnosis

\begin{tabular}{lc}
\hline Clinical characteristics & $\mathrm{N}=216(\%)$ \\
\hline Sex & $120(56)$ \\
Male & $96(44)$ \\
Female & \\
Age & $159(74)$ \\
< 45 years-old & $57(26)$ \\
$\geq 45$ years-old & \\
Stage & $70(32)$ \\
IIB & $24(11)$ \\
IIIA & $36(17)$ \\
IIIB & $21(10)$ \\
IVA & $65(30)$ \\
IVB & \\
IPS & $93(43)$ \\
0-2 & $88(41)$ \\
$\geq 3$ & $35(16)$ \\
missing & \\
Performance status & $177(82)$ \\
0-1 & $35(16)$ \\
$\geq 2$ & $4(2)$ \\
missing & \\
Histology & $154(71)$ \\
Nodular sclerosis & $42(20)$ \\
Mixed cellularity & $27(1)$ \\
Lymphocyte-rich & $5(2)$ \\
Lymphocyte depletion & $13(6)$ \\
Non-classified & \\
Bulky disease & $115(53)$ \\
No & $101(47)$ \\
Yes & \\
B symptoms & \\
No & \\
Yes & \\
Bone marrow infiltration & \\
No & \\
Yes & \\
missing & \\
\hline
\end{tabular}

patients (52\%) just received 6 to 8 chemotherapy (CT) cycles. Most remaining patients had HL in stage IIB, and were treated with two to four cycles of chemotherapy followed by radiation therapy.

\section{Outcomes}

The median follow-up time of survivors was 6.3 years (rate: 1 - 11.8 years). Fifteen patients died during first-line treatment. The complete remission rate was $80 \%$. Complete remission rates of the low-risk IPS patients and high-risk IPS patients were $88 \%$ and $72 \%$, respectively $(\mathrm{p}=0.008)$.

The 5-year progression-free survival and the 5-year overall survival probabilities were $69 \%$ and $83 \%$, respectively (Figure 1A and Figure 1B). The 5-year progression-free 

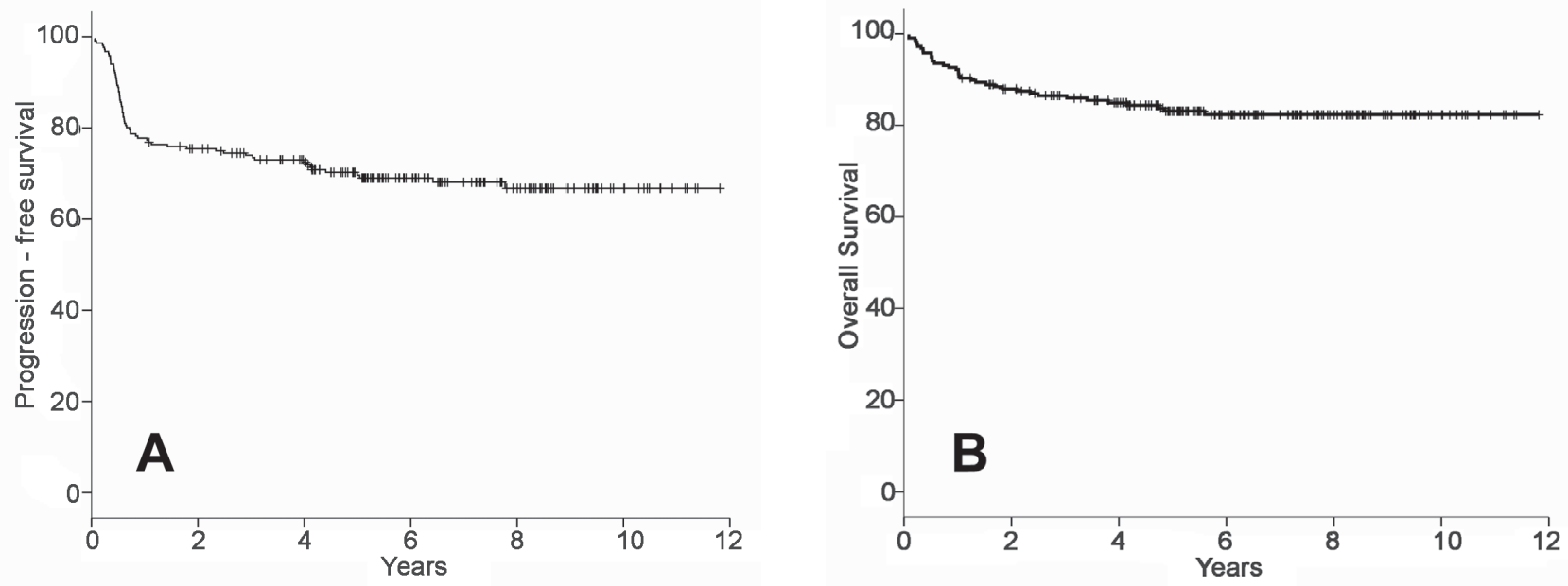

Figure 1. Progression free survival $(A)$ and overall survival curves $(B)$
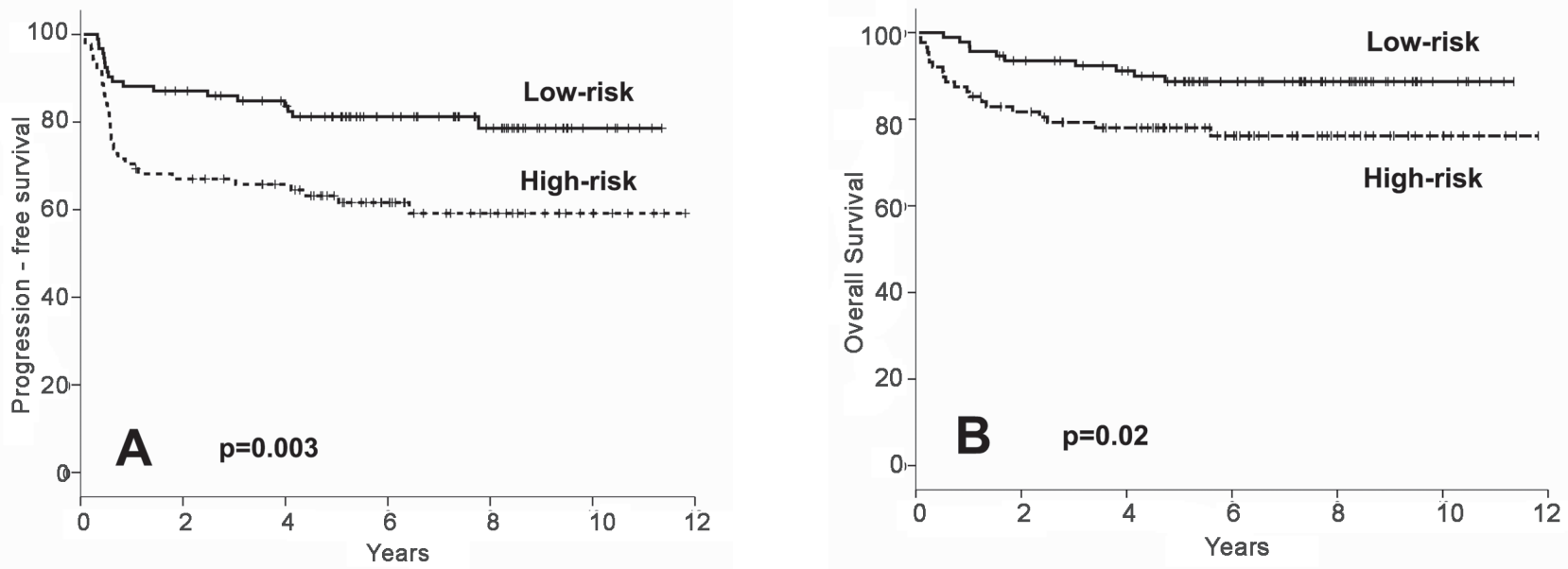

Figure 2. Progression free survival (A) an overall survival (B) curves stratified by the IPS

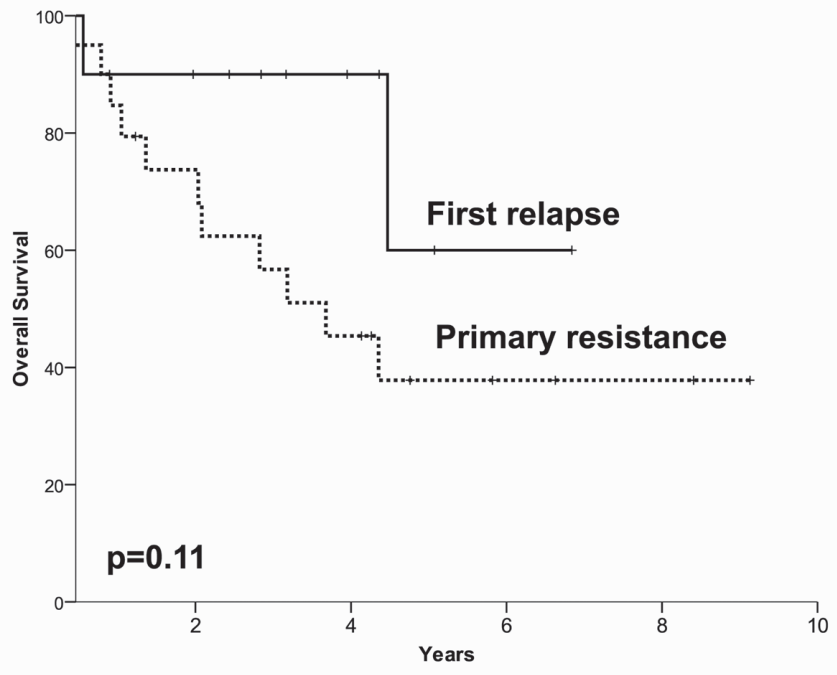

Figure 3. Overall survival curves after high-dose chemotherapy and autologous hematopoietic stem cell transplantation in patients who relapsed and in patients with primary resistance. survival probability in low-risk and high-risk patients were $81 \%$ and $62 \%(\mathrm{p}=0.003)$, respectively. The 5-year overall survival probability in low-risk and high-risk IPS patients were $89 \%$ and $78 \%(\mathrm{p}=0.02)$, respectively (Figures $2 \mathrm{~A}$ and $2 \mathrm{~B}$ ).

\section{Second-line treatment}

Sixteen patients relapsed after achieving complete remission. Among them, 62\% (10/16) were treated with highdose chemotherapy and autologous hematopoietic stem cell transplantation.

Twenty-nine patients did not achieve complete remission after first-line treatment. Among them, 69\% (20/ 29) were treated with high-dose chemotherapy and autologous hematopoietic stem cell transplantation.

The 5-year OS after high-dose chemotherapy and autologous hematopoietic stem cell transplantation in patients who relapsed and in patients with primary resistance were $60 \%$ and $38 \%$, respectively $(\mathrm{p}=0.11)$ (Figure 3 ). 


\section{Discussion}

In the current analysis, we sought to describe the outcomes of a long-term retrospective cohort of advanced HL patients treated with ABVD in three public hospitals in Rio de Janeiro, Brazil. The population treated for HL in these hospitals consists mostly of blue-collar workers and their families, as previously reported. ${ }^{2}$ Their mean household income, estimated from questionnaires that evaluate the possession of goods and the degree of instruction, is as follows: only $6 \%$ have a mean household income of over US \$ 3,000 per month; $40 \%$ have mean household incomes ranging from US $\$ 1,000$ to 1,$800 ; 31 \%$ have mean household incomes ranging from US\$ $300-600$, and $22 \%$ have mean household incomes below US\$200 per month.

It is well established that patients in underprivileged societies present with malignancies in more advanced stages. There is good evidence of this phenomenon in breast cancer and in colorectal cancer. ${ }^{3}$ In studies of HL patients treated in Brazil during the $1980 \mathrm{~s}$, most patients presented with advanced disease. ${ }^{4,5}$ However, in the present cohort, among 370 patients diagnosed with HL, only $39 \%$ had stage III or IV disease, a distribution similar to that reported in developed countries. ${ }^{6}$ Whether this represents a shift towards earlier diagnosis remains to be confirmed.

In 2003, the American Intergroup Trial reported the results of ABVD treatment in 443 patients with advanced HL. ${ }^{7}$ The complete remission rate was $76 \%$, failure-free at 5 years was $63 \%$ and overall survival at 5 years was $82 \%$. Although these results are remarkably similar to the findings in the present study, only patients with stage IIIA ${ }_{2}$ or higher were included in the Intergroup trial, and no radiotherapy was allowed.

In contrast, in the current study, almost $40 \%$ of the patients received radiotherapy after $\mathrm{ABVD}$, and patients with stage IIB and IIIA 1 were included. Therefore, while the present results are certainly acceptable, with $83 \%$ of the patients with advanced HL alive at 5 years, there appears to be room for improvement, and for more judicious use of radiotherapy.

Fifteen $(7 \%)$ of our patients died during initial treatment. We previously reported that those early deaths are more common in patients with a lower socio-economic status. ${ }^{2}$ There are many potential reasons for this, including comorbidities, longer distance and transportation shortcomings between residences and treatment centers, a lower threshold in identifying symptoms related to lifethreatening complications, and lack of social support.

The retrospective nature of this study imposed some limitations that could not be circumvented. Although all patients were treated with ABVD, decisions regarding the number of cycles and the use radiotherapy were often taken by the attending physicians during treatment, according to the interim clinical evaluation, without compulsory pre- allocation to a given treatment strategy. For instance, one patient with a good response after ABVD might have proceeded to radiotherapy, while another with evidence of disease might have been considered as treatment failure and sent for second-line treatment before attempting radiotherapy. Comparisons regarding these treatment variables were therefore avoided. Data regarding long-term follow-up were missing for many patients, and therefore it is not possible to assess whether the frequent use of associated radiotherapy had long-term consequences for these patients.

\section{Conclusion}

The present study provides a representative estimate of current treatment results for advanced HL in public institutions in an urban area in Brazil. It is clear that full treatment can be given to most patients, although those with very low socio-economic status might require special attention and support. Since Brazil is a large country, with substantial inter-regional heterogeneity, a nationwide registry of HL patients is currently being implemented.

\section{Resumo}

Os resultados do tratamento do linfoma de Hodgkin (LH) melhoraram substancialmente ao longo das últimas décadas e tornaram o LH uma das neoplasias humanas com maior chance de cura. Entretanto, os dados sobre tratamento em países em desenvolvimento são escassos. Entre 1996 e 2005, 370 pacientes consecutivos com LH tratados em três instituições públicas no Rio de Janeiro foram identificados. Destes, $216 \mathrm{em}$ estádio avançado (IIB-IV) foram selecionados para esta análise. Os pacientes foram tratados com o protocolo ABVD (doxorrubicina, bleomicina, vinblastina e dacarbazina). A mediana do tempo de seguimento dos sobreviventes foi de 6,3 anos (1-11,8). Quinze pacientes morreram durante o tratamento de primeira linha. A probabilidade de sobrevida livre de progressão (SLP) em cinco anos e a probabilidade de sobrevida global (SG) em cinco anos foram de $69 \%$ e $83 \%$, respectivamente. A SLP nos grupos de baixo risco e de alto risco, de acordo com o "International Prognostic Score", foi de $81 \%$ e $62 \%(p=0,003)$, respectivamente. A SG em cinco anos nos grupos de baixo risco e de alto risco foi de $89 \%$ e $78 \%$ $(p=0,02)$, respectivamente. $O$ presente estudo apresenta uma estimativa representativa dos resultados atuais do tratamento do LH avançado em instituições públicas no Brasil. Fica claro que o tratamento completo pode ser oferecido à grande maioria dos pacientes, embora aqueles com baixo status socioeconômico possam exigir atenção especial. Em vista das dimensões continentais do Brasil, com substancial heterogeneidade inter-regional, um registro nacional de pacientes com LH está sendo implementado. Rev. Bras. Hematol. Hemoter. 2010;32(4):303-307.

Palavras-chave: Doença de Hodgkin; quimioterapia; linfoma. 


\section{References}

1. Werdlow SH CE, Harris NL, Jaffe ES, Pileri SA, Stein H, Thiele J, Vardiman JW. Pathology and genetics of tumours of hematopoietic and lymphoid tissues. World Health Organization classification of tumours. International Agency for Research on Cancer Press, Lyon 2008.

2. Soares A, Biasoli I, Scheliga A, Luiz RR, Costa MA, Land M, et al. Socioeconomic inequality and short-term outcome in Hodgkin's lymphoma. Int J Cancer. 2007;120(4):875-9.

3. Woods LM, Rachet B, Coleman MP. Origins of socio-economic inequalities in cancer survival: a review. Ann Oncol. 2006; 17(1): 5-19.

4. Spector N, Costa MA, Pulcheri W, Salgado RC, Nucci M, Andrade $\mathrm{CA}$, et al. C-MOPP/ABV yields good results in a public hospital population with Hodgkin disease in Brazil. Cancer. 1993;71(9): 2823-7.

5. de Souza CA, Vassallo J, Lorand-Metze I. Hodgkin's disease in Brazil: a clinicopathologic study. Haematologica. 1997;82 (1): 127-8.

6. Kennedy BJ, Fremgen AM, Menck HR. The National Cancer Data Base report on Hodgkin's disease for 1985-1989 and 1990-1994. Cancer. 1998;83(5):1041-7.

7. Duggan DB, Petroni GR, Johnson JL, Glick JH, Fisher RI, Connors $\mathrm{JM}$, et al. Randomized comparison of ABVD and MOPP/ABV hybrid for the treatment of advanced Hodgkin's disease: report of an intergroup trial. J Clin Oncol. 2003;21(4):607-14.

Avaliação: Editor e dois revisores externos

Conflito de interesse: sem conflito de interesse

Recebido: 30/03/2010

Aceito após modificações: 08/06/2010 